\title{
What is The Success Rate of Patients Using Warfarin in Maintaining Their Target International Normalized Ratio Levels?
}

\section{Varfarin Kullanan Hastaların Hedef Uluslararası Normalleștirilmiş Oran Başarısı ne Kadar İyi?}

\author{
Tuğba Atmaca Temrel', Serkan Sahin², İshak Şan ${ }^{1}$ \\ ${ }^{1}$ University of Health Sciences Ankara Numune Health Practice and Research Center, Department of \\ Emergency Medicine \\ ${ }^{2}$ Bolu Abant İzzet Baysal State Hospital, Department of Emergency Medicine
}

\begin{abstract}
Objectives: Patients using warfarin, are also referred to emergency departments when they have an emergency. When a patient using warfarin presented to the emergency departments to be able to estimate the possible level of International Normalized Ratio can help in making an emergency treatment plan. The purpose of this study was to demonstrate patient success in maintaining International Normalized Ratio by investigating spot International Normalized Ratio levels of patients using warfarin who were admitted to emergency services.

Materials and Methods: Our study is survey study. Among 2071 patients, 129 patients using warfarin due to non-valvular causes who were admitted to the emergency departments for warfarin-unrelated reasons and who met the inclusion criteria were included in the study.

Results: $41.80 \%$ of the participants had International Normalized Ratio values within the therapeutic range. It was shown that warfarin-related bad experiences and having training did not affect whether International Normalized Ratio was within the therapeutic range or not.

Conclusion: Patients using warfarin are unsuccessful in maintaining their target International

Normalized Ratio levels. New policies and programs should be developed to protect the target International Normalized Ratio levels.

Key Words: Warfarin, international normalized ratio, emergency medicine
\end{abstract}

$\ddot{O} \mathbf{z}$

Amaç: Varfarin kullanan hastalar, acil durumları olduğunda acil servislere bașvururlar. Varfarin kullanan bir hasta acil servise başvurduğunda olası Uluslararası Normalize Oran düzeyini tahmin edebilmek acil tedavi planının yapılmasına yardımcı olabilir. Bu çalıșmada acile başvuran ve varfarin kullanan hastaların o anki spot Uluslararası Normalize Oran düzeyleri incelenerek hastaların Uluslararası Normalize Oran kontrolündeki başarılarının gösterilmesi amaçlandı.

Materyal ve Metot: Çalıșmamız bir anket çalışmasıdır. 2071 hastadan non valvüler nedenli varfarin kullanan, varfarin ilişkisiz bir nedenden dolayı acil servise başvuran ve dahil etme kriterlerini karşılayan 129 hasta çalıșmaya kabul edildi.

Bulgular: Katılımcıların \% 41,80'inin Uluslararası Normalize Oran'ı terapotik aralıktaydı. Uluslararası Normalize Oranın terapotik aralıkta olup olmamasında varfarin ilișkili kötü tecrübelerin ve eğitim almış olmanın etkisinin olmadığı gösterildi.

Sonuç: Hastalar hedef Uluslararası Normalize Oran düzeylerini korumada başarısızdır. Hedef Uluslararası Normalize Oranı korumak için yeni politikalar ve programlar geliștirilmelidir.

Anahtar Kelimeler: Varfarin, uluslararası normalleștirilmiș oran, acil servis

Yazıșma Adresi / Correspondence:

Dr. Tuğba Atmaca Temrel

e-mail: tugbatemrel@gmail.com

Date of submission: 31.12 .2018

Date of admission: 14.05.2019 
What is The Success Rate of Patients Using Warfarin in Maintaining Their Target International Normalized Ratio Levels?

\section{Introduction}

Since its discovery in 1920, warfarin has been one of the major medicines of the World Health Organization due to its positive characteristics such as anticoagulant activity and cost effectiveness, and is currently the most widely used anticoagulant agent worldwide. ${ }^{1}$

Warfarin is indicated for the treatment and prophylaxis of mechanical heart valve, atrial fibrillation and thrombus formation in deep veins. ${ }^{2}$ Warfarin exerts its anticoagulant activity by inhibiting gamma carboxylation of factors II, VII, IX and X, which are Vitamin K-dependent. ${ }^{3}$ It is monitored by International normalized ratio (INR). International normalized ratio is calculated by dividing the geometric mean of the prothrombin time (PT) of the healthy adult population by the normal prothrombin time. The normal level of a healthy person's INR is generally considered to be 1 (o.81.2), although it varies according to testing laboratories. An INR level of 2 indicates that the clotting time is doubled. INR level is regulated according to the patient's clinic, but the most widely accepted therapeutic range is between 2 to $3 .{ }^{4}$ Monitor ability of warfarin, the presence of flow charts and guidelines describing the intervention according to patient's INR level and presence or absence of hemorrhage findings, and the fact that the anticoagulant effect can be antagonized when necessary increase the prescribability of warfarin.5-7 The most common adverse effect associated with warfarin is hemorrhage. Warfarin ranks third in admittance to hospital due to side effects. The relation between coagulation above the therapeutic range and increased hemorrhage and the relation between coagulation below the therapeutic range and increased thromboembolic events are other conditions that the clinician should consider when prescribing warfarin $.8,9$

Patients who use anticoagulant agents are usually the elderly. The use of warfarin in geriatric patients is limited by factors such as comorbid diseases, impaired renal and hepatic function, other medications used, easy interaction of warfarin with other drugs, genetic polymorphism which affects warfarin, and changes in warfarin activity due to the interaction of enzymes in warfarin metabolism with foods. ${ }^{10,11}$ As a result of these limitations, complications associated with warfarin are inevitable. Cooperating with the patient in maintaining target INR levels and encouraging patient participation during the process, increasing the knowledge level of patients related to warfarin use, and increasing INR control capabilities can lead to clinical and cost benefits. ${ }^{12}$

Emergency departments (EDs) provide healthcare to patients from a wide range of clinical settings. Patients using warfarin, like every patient, are also referred to EDs when they have an emergency. In addition to the risks inherent in warfarin itself, it also carries the risk of thromboembolic or hemorrhagic complications when used not effectively. However, there are not enough social studies explaining how effectively these patients use warfarin in their daily lives, and what issues they experience due to warfarin use. Therefore, the purpose of this study was to investigate the success of INR control in patients using warfarin.

\section{Materials and Methods}

Approval was obtained from our hospital's ethical committee for this study $(2016 / 250)$. 
Study Group: This study was conducted between 01.10.2016 and 31.12.2016. Inclusion criteria for the study were defined as admittance to our ED for any reason, using warfarin for non-valvular reasons, INR examination planning by the emergency physician, providing consent for participating in this study, and being over 18 years of age. Survey questions were asked during face-to-face interviews. Verbal consent was received from the participants. During the course of our study, out of 2071 patients referred to the researcher during working hours, 129 consecutive patients who met the inclusion criteria were included in the study. Since one patient was newly prescribed with warfarin, two patients were in the dose-setting phase, and INR levels of four patients could not be obtained due to laboratory errors, seven patients were excluded from the study and the data of 122 patients were analyzed (Figure 1). Major hemorrhage was defined as hemorrhage requiring 2 units of erythrocyte suspension or hemorrhage at a critical anatomic site (intracranial, retroperitoneal, etc.). ${ }^{13}$

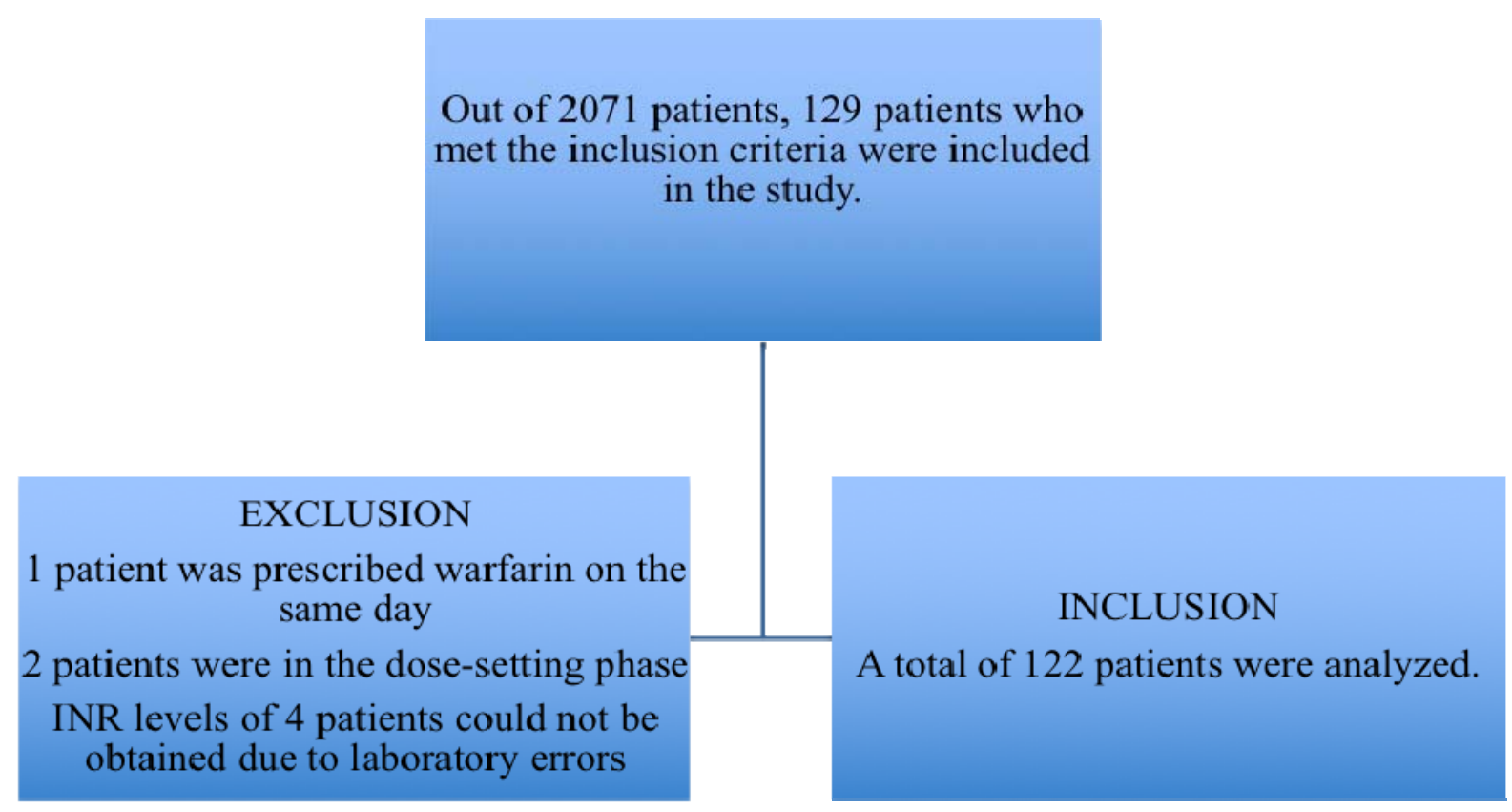

Figure 1. Diagram of the study group

Major complications was defined as gastrointestinal hemorrhage, ectopic pregnancy rupture, intracranial hemorrhage, intra-abdominal hemorrhage, retroperitoneal hemorrhage, and hemothorax. Minor complications was defined as ecchymosis, conjunctival hemorrhage, hematuria, epistaxis, gingival bleeding and intraarticular hemorrhage.

Blood products in taking medical history was defined as use due to warfarin overdose. This blood products was desribed as erythrocyte, fresh frozen plasma, factor concentrates and platelet suspension.

Statistical Analysis: All statistical analyses were performed using the SPSS software (version 19.o, SPSS Inc., Chicago, IL). Descriptive measures of the variables were calculated. Categorical variables were presented as frequency and percentage, while continuous variables were presented as mean $\pm \mathrm{SD}$ in tabular form. Continuous numerical variables were analyzed by the Kolmogorov-Smirnov method for normal distribution. It was seen that the variables did not fit normal distribution. For this 
What is The Success Rate of Patients Using Warfarin in Maintaining Their Target International Normalized Ratio Levels?

reason, Mann - Whitney U test was used for independent group comparisons between two groups, and Kruskal - Wallis test was used for comparison of multiple groups.

Friedman Two-way ANOVA technique was used for dependent measurements. Paired comparisons were made in multiple comparisons which were significant. Groups found to be significantly different were shown using exponents in the tables. Type-I error rate was defined as $5 \%$ throughout the study, and $\mathrm{p}<0.05$ was accepted as statistically significant.

\section{Results}

The mean age of our study group was $68.07 \pm 14,25$ and the median duration of warfarin use was 6.00 ( $\min 0.10-\max 38.00$ ) years. The mean age of the group with hypotherapeutic INR was $64,17 \pm 16,81$, and the median duration of warfarin use was 4.00 ( $\min 1$-max 22) years. The mean age of participants who had INR in the therapeutic range was $70,12 \pm 12,42$, and the median duration of warfarin use was 8.00 (min 0.10-max 38.00) years. The mean age of the group with overcoagulation was $68,29 \pm 14,22$, and the median duration of warfarin use was 4.50 (min-0.40-max 23.00) years. $62.30 \%(n=76)$ of the study group consisted of female and $81.10 \%(n=99)$ of the participants were married. The occupations of the participants were housewife (55.70\%, $\mathrm{n}=68)$, retired $(27.90 \%, \mathrm{n}=34)$, and worker $(7 \cdot 40 \%, \mathrm{n}=9)$.

Spontaneous INR levels of $58.20 \%(n=71)$ of the participants were not in the therapeutic range. $23.80 \%(\mathrm{n}=29)$ of the participants had INR levels in the hypocoagulated range and $34.40 \%(n=42)$ were in the supratherapeutic range. $44.30 \%$ $(n=54)$ of the participants stated they applied to the hospital once a month to check their INR levels. $59.80 \%(n=73)$ of the participants stated that they received training on the use of warfarin.

Major complication rate within the study group was $13.90 \%(n=17)$ and minor complication rate was $29.50 \%(n=36) .86 .10 \%(n=105)$ of the study group did not have any major complications in the past. The most common major complication was gastrointestinal hemorrhage $(10.60 \%, \mathrm{n}=13)$. Two participants had intracranial hemorrhage (1.60\%), one participant had ectopic pregnancy rupture $(0.80 \%)$, and one participant had intra-abdominal hemorrhage (0.80\%).

$70.50 \%(n=86)$ of the participants did not have any minor complications, and the most common minor complication was skin echymosis $(11.50 \%, n=14)$. Other minor complications included epistaxis $(8.20 \%, \mathrm{n}=10)$, hematuria $(4.10 \%, \mathrm{n}=5)$, gingival hemorrhage $(1.60 \%, n=2)$ and conjunctiva hemorrhage $(0.80 \%, n=1)$.

$73 \%(\mathrm{n}=90)$ of our participants were found to have previously used blood products related to warfarin at least once. The general characteristics of the study group are shown in Table 1.

$52.63 \%(n=40)$ of women were in the therapeutic range. There was statistically significant difference between the groups with respect to INR levels by gender ( $p$ $<0.001)$. No difference was found between groups when warfarin use indications were evaluated according to INR levels $(\mathrm{p}=0.542)$. There was no significant difference between having used blood products, warfarin-induced complications history and spot INR levels (Respectively; $\mathrm{p}=0.420, \mathrm{p}=0.440, \mathrm{p}=0.926$ ). The hospitalization history of the study group due to a warfarin-related cause was 22 persons. 
What is The Success Rate of Patients Using Warfarin in Maintaining Their Target International Normalized Ratio Levels?

Table 1: General Characteristics of the Study Group

\begin{tabular}{|l|l|c|c|}
\hline Characteristics & $\mathbf{n}^{*}$ & $\mathbf{\%}^{*}$ \\
\hline \multirow{2}{*}{ Gender } & Female & 76 & 62.29 \\
& Male & 46 & 37.70 \\
\hline \multirow{2}{*}{ Marital Status } & Married & 99 & 81.14 \\
& Single & 23 & 18.85 \\
\hline \multirow{5}{*}{ Occupation } & Housewife & 68 & 55.73 \\
& Retired & 34 & 27.86 \\
& Worker & 9 & 7.37 \\
& Self-employed & 6 & 4.91 \\
& Civil Servant & 3 & 2.45 \\
Settlement Unit & Unemployed & 1 & 0.81 \\
& Student & 1 & 0.81 \\
\hline Training on Warfarin & City & 79 & 64.75 \\
Use & District & 32 & 26.22 \\
\hline \multirow{3}{*}{ INR Level } & Received & 11 & 9.01 \\
& Not Received & 73 & 59.83 \\
\hline Previous Blood Product & Low (2>) & 49 & 40.16 \\
\hline Use & Therapeutic (2-3) & 29 & 23.77 \\
INR follow-up frequency & Yigh (3<) & 42 & 41.80 \\
& No & 90 & 34.42 \\
\hline Major Complication & Once a month & 32 & 26.77 \\
\hline History & Not regular & 54 & 44.26 \\
\hline Minor Complication & No & 36 & 29.50 \\
History & Yes & 32 & 26.22 \\
\hline & No & 17 & 13.93 \\
\hline
\end{tabular}

${ }^{*}$ Total is $\mathrm{n}=122$ and equal to $100 \%$

There was no correlation between hospitalization history and spot INR levels $(\mathrm{p}=$ o.977). 73 participants stated that they had received training on how to use warfarin. There was no correlation between receiving training on warfarin use and INR levels ( $\mathrm{p}$ $=0.749$ ). (Table 2)

\section{Discussion}

Patients are admitted to EDs suddenly and without any planning. In emergency applications, preparations such as fasting, satiety or body welfare that are regularly performed for outpatient clinic visits cannot be performed most of the time. Patients using warfarin can also apply to EDs suddenly with the current INR status. Our study showed that when a patient using warfarin applied to EDs, the patient's INR value at that moment was more likely to be outside the target range. 
What is The Success Rate of Patients Using Warfarin in Maintaining Their Target International Normalized Ratio Levels?

Table 2. Characteristics of the Study Group according to Spot INR Levels

\begin{tabular}{|c|c|c|c|c|c|c|}
\hline \multirow{2}{*}{\multicolumn{2}{|c|}{$\begin{array}{l}\text { Characteristic } \\
\text { n }(\%)\end{array}$}} & \multicolumn{3}{|c|}{ INR } & \multirow{3}{*}{$\begin{array}{c}\text { Total } \\
76 \\
(100.00)\end{array}$} & \multirow{2}{*}{$\mathbf{p}$} \\
\hline & & $2>$ & $2-3$ & $3<$ & & \\
\hline \multirow{2}{*}{ Gender } & Female & $11(14 \cdot 47)$ & $40(52.63)$ & $25(32.89)$ & & \multirow{2}{*}{$<0.001$} \\
\hline & Male & $18(39.13)$ & $11 \quad(23.91)$ & $17(36.95)$ & $\begin{array}{c}46 \\
(100.00)\end{array}$ & \\
\hline \multirow{4}{*}{ Indication } & $\mathrm{AF}$ & $20(22.22)$ & $40(44.44)$ & $30(33.33)$ & $\begin{array}{c}90 \\
(100.00)\end{array}$ & \multirow{4}{*}{0.542} \\
\hline & Stroke & $4(18.18)$ & $9(40.91)$ & $9(40.91)$ & $\begin{array}{c}22 \\
(100.00)\end{array}$ & \\
\hline & PTE-DVT & $3(50.00)$ & $1(16.67)$ & $2(33.33)$ & $\begin{array}{c}6 \\
(100.00)\end{array}$ & \\
\hline & $\begin{array}{l}\text { Does not } \\
\text { remember }\end{array}$ & $2(50.00)$ & $1(25.00)$ & $1(25.00)$ & $\begin{array}{c}4 \\
(100.00)\end{array}$ & \\
\hline \multirow{2}{*}{$\begin{array}{l}\text { Previous } \\
\text { Blood } \\
\text { Product } \\
\text { Use }\end{array}$} & Yes & $\begin{array}{c}22 \\
(24.44) \\
\end{array}$ & $\begin{array}{c}40 \\
(44.44) \\
\end{array}$ & $28(31.11)$ & $\begin{array}{c}90 \\
(100.00) \\
\end{array}$ & \multirow{2}{*}{0.420} \\
\hline & No & $7(21.87)$ & $11(34 \cdot 37)$ & $14(43.75)$ & $\begin{array}{c}32 \\
(100.00)\end{array}$ & \\
\hline \multirow{2}{*}{$\begin{array}{l}\text { Major } \\
\text { Complicati } \\
\text { on History }\end{array}$} & Yes & $4(23 \cdot 52)$ & $5(29.41)$ & $8(47.05)$ & $\begin{array}{c}17 \\
(100.00)\end{array}$ & \multirow{2}{*}{0.440} \\
\hline & No & $25(23.80)$ & $46(43.80)$ & $34(32.38)$ & $\begin{array}{c}105 \\
(100.00)\end{array}$ & \\
\hline \multirow{2}{*}{$\begin{array}{l}\text { Minor } \\
\text { Complicati } \\
\text { on History }\end{array}$} & Yes & $8(22.22)$ & $16(44.44)$ & $12(33 \cdot 33)$ & $\begin{array}{c}36 \\
(100.00)\end{array}$ & \multirow{2}{*}{0.926} \\
\hline & No & $21(24.41)$ & 35 (40.69) & $30(34.88)$ & $\begin{array}{c}86 \\
(100.00)\end{array}$ & \\
\hline \multirow{2}{*}{$\begin{array}{l}\text { Previous } \\
\text { Hospitaliz } \\
\text { ation }\end{array}$} & Yes & $5(22.72)$ & $9(40.90)$ & $8(36.36)$ & $\begin{array}{c}22 \\
(100.00)\end{array}$ & \multirow{2}{*}{0.977} \\
\hline & No & $24(24.00)$ & $42(42.00)$ & $34(34.00)$ & $\begin{array}{c}100 \\
(100.00) \\
\end{array}$ & \\
\hline \multirow{2}{*}{$\begin{array}{l}\text { Warfarin } \\
\text { Training }\end{array}$} & Yes & $19(26.02)$ & $29(39.72)$ & $25(34.24)$ & $\begin{array}{c}73 \\
(100.00)\end{array}$ & \multirow[t]{2}{*}{0.749} \\
\hline & No & $10(20.40)$ & $22(44.89)$ & $17(34.69)$ & $\begin{array}{c}49 \\
(100.00)\end{array}$ & \\
\hline
\end{tabular}

AF: Atrial Fibrillation

PTE: Pulmonary Thromboembolism

DVT: Deep Vein Thrombosis

Only $41.8 \%$ of participants of our study were in the therapeutic range. There are studies involving patients applying to EDs due to warfarin-related complications, and the ratio of patients within the therapeutic range is generally consistent with our findings. ${ }^{1-16}$ Although an increase in INR level from 1 to 2 indicates a twofold hemorrhage risk, it has been reported that the incidence of intracranial hemorrhage is 
What is The Success Rate of Patients Using Warfarin in Maintaining Their Target International Normalized Ratio Levels?

higher after values greater than 3.9.4,17 The supratherapeutic INR rate in our study was $34.4 \%$ and the number of participants who reported major hemorrhage in the past was higher compared to the general literature (13.9\%). ${ }^{13}, 15,18$ The most common cause of warfarin use in our study was atrial fibrillation, which is consistent with the literature. ${ }^{19}$ An INR level below 2 has been shown to increase ischemic stroke in atrial fibrillation and it is associated with poor prognosis and mortality ${ }^{17}$ Warfarin-related complications continue to be a burden on health systems worldwide and result in disruptive consequences for individuals. ${ }^{20} 23 \%$ of our participants had an INR level below 2, and the clinical consequences of thromboembolic events that may arise from such an INR level are not clear. In our study, we also found a strikingly high ratio of warfarin-related blood product use in the past (73.8\%). This ratio includes erythrocyte suspension support in major hemorrhage, minor hemorrhage that still requires erythrocyte suspension support, platelet suspension, and fresh frozen plasma transfusion intended to antagonize warfarin's effect. In our study, we also found a high warfarin-related hospitalization rate (18\%). The complications of warfarin-related blood product transfusion in these people, and the additional burden of treatment and admission processes to healthcare systems are unknown.

Another important result of our study is patient training about how to use warfarin. In their review, Newall et al. reported that increasing the knowledge level of patients and their families was proportional to a decrease in complications such as major hemorrhage. ${ }^{21}$ In the study of Stafford et al., it was reported that the patients had poor knowledge, which is resulted in suboptimal INR levels and subsequently unwanted outcomes. ${ }^{20}$ Our findings support this view. More than half of our participants (59.8\%) stated that they had received training on warfarin use. However, looking at the INR values, it can be said that this training is not reflected on INR levels. Similarly, our patients did not learn from past experiences such as previous hemorrhage stories, hospitalization stories, or blood transfusion stories. This result suggests that the involvement of the patient in this process is necessary in warfarin use and the management of INR. Patients should take responsibility for maintaining their target INR levels. Patients who participate in the follow-up of their target INR and take responsibility increase the quality of anticoagulation therapy. ${ }^{22}$ Face-to-face training possibilities and trainings provided as part of the doctor-patient relationship can be implemented to assist patients in maintaining their target INR levels. Anticoagulation clinics and technological support such as online messaging platforms and finger-tip devices can also be utilized. ${ }^{12,20,21,23}$

While evaluation using only a single INR result seems like a limitation of the study, it is very important in terms of showing the spot INR status at that time. More than half of the participants were not in the therapeutic range. This group carries the risk of admission to EDs with potential thromboembolic or vascular complications. Furthermore, it is known that $0.5-1.5 \%$ of the world population is using warfarin. ${ }^{4}$ In the UK, $1 \%$ of the overall population and $8 \%$ of the population over 80 years of age are using warfarin. ${ }^{9}$ It is estimated that by 2020 there will be 7.5 million atrial fibrillation cases in the US alone, and another study estimates that one in twelve Americans will experience at least one venous thromboembolism in their lives. ${ }^{24}$ These findings indicate that the use of warfarin will continue to increase in the near future. Therefore, 
What is The Success Rate of Patients Using Warfarin in Maintaining Their Target International Normalized Ratio Levels?

if higher success rates cannot be achieved in maintaining target INR values, it can be concluded that the incidence of warfarin related complications in EDs will increase.

There is some limitations, we didn't have a lots of participants and we couldn't ask thromboembolic complications.

In conclusion, patients using warfarin are unsuccessful in maintaining their target INR levels. It would be useful for emergency physicians to assume that the patients they encounter in the EDs who are using warfarin are likely to have an INR level out of the therapeutic range when deciding on treatments and interventions. In addition, patient awareness is a step that should not be neglected in maintaining target INR values. Systems that adopt a multidisciplinary approach and offer face-to-face training have been shown to be associated with the most successful results. ${ }^{21}$ The importance of achieving and maintaining target INR levels should be taught to patients using warfarin. Healthcare providers should adopt an appropriate training system and provide effective patient training for high quality anticoagulation treatment.

\section{References}

1. Joppa SA, Salciccioli J, Adamski J, Patel S, Wysokinski W, McBane R. Review A Practical Review of the Emerging Direct Anticoagulants, Laboratory Monitoring. Reversal Agents, J. Clin. Med. 2018, 7, 29 (doi:10.3390/jcm7020029)

2. Levine M, Pizon AF, Padilla-Jones A, Ruha, AM. Warfarin Overdose: A 25-Year Experience. J. Med. Toxicol. (2014) 10:156-164 (doi: 10.1007/s13181-013-0378-8)

3. Funk DM. Coagulation assays and anticoagulant monitoring. American Society of Hematology, Hematology (2012) 460-5

4. Wen MS, Lee MM. Warfarin Pharmacogenetics: New Life for an Old Drug. Acta Cardiol Sin 2013;29:235-42

5. 5-Garcia DA, Crowther M. Reversal of Warfarin Case-Based Practice Recommendations. Circulation 2012 Jun 12;125(23):2944-7. (doi:10.1161/CIRCULATIONAHA.111.081489)

6. Holbrook A, Schulman S, Witt DM et al. Evidence-Based Management of Anticoagulant Therapy Antithrombotic Therapy and Prevention of Thrombosis, gth ed: American College of Chest Physicians Evidence-Based Clinical Practice Guidelines. CHEST 2012; 141(2)(Suppl):e152Sei $84 \mathrm{~S}$

7. Keeling D, Baglin T, Tait $C$ et al. Guidelines on oral anticoagulation with warfarin - fourth Edition. British Journal of Haematology, 2011;154(3):311-24 (doi:10.1111/j.1365-2141.2011.08753.x)

8. Rolfe S, Papadopoulos S, Cabral PK. Controversies of Anticoagulation Reversal in LifeThreatening Bleeds. Journal of Pharmacy Practice 23(3):217-25 (doi: 10.1177/0897190010362168)

9. Pirmohamed M. Warfarin: almost 60 years old and still causing problems. British Journal of Clinical Pharmacology 2006; 62: 509-11 (doi:10.1111/j.1365-2125.2006.02806.x)

10. Farinola N, Caughey GE, Bell JS, Johns S, Hauta-aho M, Shakib S. Influence of stroke and bleeding risk on prescribing of oral anticoagulants in older in patients; has the availability of direct oral anticoagulants changed prescribing? Therapeutic Advances in Drug Safety, 2018; 9(2): 113-21 (doi: 10.1177/2042098617747835)

11. Gokcal E, Pasi M, Fisher M, Gurol ME. Atrial Fibrillation for the Neurologist: Preventing both Ischemic and Hemorrhagic Strokes. Current Neurology and Neuroscience Reports 2018; 18(2):6 (https://doi.org/10.1007/s11910-018-0813-y)

12. Smith DE, Xuereb CB, Pattison HM, Lip GYH, Lane D. STRial of an Educational intervention on patients' knowledge of Atrial fibrillation and anticoagulant therapy, INR control, and outcome of Treatment with warfarin (TREAT). BMC Cardiovascular Disorders 2010; 10:21 (http://www.biomedcentral.com/1471-2261/10/21)

13. Roskell NS, Samuel M, Noack H, Monz BU. Major bleeding in patients with atrial fibrillation receiving vitamin $\mathrm{K}$ antagonists: a systematic review of randomized and observational studies. Europace 2013; 15: 787-97 (doi:10.1093/europace/eutoo1) 
What is The Success Rate of Patients Using Warfarin in Maintaining Their Target International Normalized Ratio Levels?

14. Yu HY, Lin MH, Lin LY, Wang CH, Chi NH, Chen YS. Do Patients With High CHA2DS2-VASc Scores Need High Intensity of Anticoagulants After Valve Surgery? Circ J 2018;82(4):1186-94 (doi: 10.1253/circj.CJ-17-1172)

15. Boulanger L, Kim J, Friedman M, Hauch O, Foster T, Menzin J. Patterns of use of antithrombotic therapy and quality of anticoagulation among patients with non-valvular atrial fibrillation in clinical practice. Int J Clin Pract, March 2006;60(3):258-64 (doi : 10.1111/ j.13685031. $2005.00790 . x)$

16. Sayhan MB, Oğuz S, Yüksel V, Hüseyin S, Sayhan ES, Yağcı G. The Analysis of Patients Admitted to the Emergency Department Due to Complications Related to Warfarin Treatment. JAEM 2014; 13: 194-8( doi: 10.5152/jaem.2014.075)

17. Hylek EM, Go AS, Chang Y, et al. Effect of Intensity of Oral Anticoagulation on Stroke Severity and Mortality in Atrial Fibrillation. The New England Journal of Medicine, N Engl J Med 2003;349:1019-26.

18. Hylek EM, Evans-Molina C, Shea C, Henault LE, Regan S. Major Hemorrhage and Tolerability of Warfarin in the First Year of Therapy Among Elderly Patients With Atrial Fibrillation. Circulation 2007;115:2689-96

19. Green L, Tan J, Morris JK, et al. A three-year prospective study of the presentation and clinical outcomes of major bleeding episodes associated with oral anticoagulant use in the UK (ORANGE study). Haematologica. 2018;103:1-18 (doi:10.3324/haematol.2017.182220)

20. Stafford L, Tienen EC, Bereznicki L, Peterson GM. The benefits of pharmacist-delivered warfarin education in the home. International Journal of Pharmacy Practice 2012; 20:384-9

21. Newall F, Monagle P, Johnston L. Patient understanding of warfarin therapy: A review of education strategies. Hematology, 2005;10(6):437-42 (doi:10.108o/10245330500276451)

22. Heneghan CJ, Garcia-Alamino JM, Spencer EA, et al.Self-monitoring and self-management of oral anticoagulation. Cochrane Database of Systematic Reviews 2016;7 (doi: 10.1002/14651858.CDoo3839.pub3.)

23. Jenner KM, Simmons BJ, Delate T, Clark NP, Kurz D, Witt DM. An Education Program for Patient Self-Management of Warfarin. Perm J 2015;19(4):33-8 (http://dx.doi.org/10.7812/TPP/14246 )

24. Dar T, Yarlagadda B, Vacek J, Dawn B, Lakkireddy D. Management of Stroke Risk in Atrial Fibrillation Patients with Bleeding on Oral Anticoagulation Therapy-Role of Left Atrial Appendage Closure, Octreotide and more. Journal of Atrial Fibrillation 2017; 10(4):1729. 